Naoto Maeda • Yutaka Horie • Kaori Adachi • Eiji Nanba

Hironaka Kawasaki • Makoto Daimon • Yoshiro Kudo

Masao Kondo

\title{
Two deletion mutations in the hydroxymethylbilane synthase gene in two unrelated Japanese patients with acute intermittent porphyria
}

Received: March 13, 2000 / Accepted: May 22, 2000

\begin{abstract}
Acute intermittent porphyria (AIP) is an autosomal dominant inherited disease caused by a decreased activity of hydroxymethylbilane synthase (HMBS). Regarding the abnormalities of the HMBS gene, many different mutations have been reported worldwide; however, few families from Japan have been studied. In this work, we investigated the presence of mutations in two unrelated Japanese patients with AIP. Mutational analysis was performed using the polymerase chain reaction-single strand conformation polymorphism (SSCP) method, followed by DNA sequencing. Reliable restriction enzyme cleavage assays were also established for the pedigree analyses. Unique SSCP patterns were noted in exons 12 and 15 of the $H M B S$ gene. Sequencing revealed different mutations in each patient: a two-base deletion of CT at nucleotide 730-731 (730delCT), and also a two-base deletion of CA at position 982-983 (982delCA). Both of the deletion mutations lead to truncated proteins with an abnormal C-terminus, which would be expected to decrease the stability and/or activity of HMBS. Using the cleavage assays, we were able to definitively identify gene carriers in the family. This study adds a novel mutation to those that have been previously reported, and emphasizes that molecular analysis would be very useful not only for the identification of asymptomatic gene
\end{abstract}

N. Maeda $(\bowtie) \cdot$ Y. Horie $\cdot$ H. Kawasaki

Second Department of Internal Medicine, Faculty of Medicine,

Tottori University, Yonago 683-8503, Japan

Tel. +81-859-34-8103; Fax +81-859-34-8139

e-mail: nmaeda@grape.med.tottori-u.ac.jp

K. Adachi · E. Nanba

Gene Research Center, Tottori University, Yonago, Japan

M. Daimon

Third Department of Internal Medicine, Yamagata University

School of Medicine, Yamagata, Japan

Y. Kudo

Department of Preventive Medicine, St. Marianne University School of Medicine, Kawasaki, Japan

M. Kondo

Department of Nutrition and Biochemistry, National Institute of

Public Health, Tokyo, Japan carriers in the family but also for the detection of ancestral founders in porphyria families.

Key words Acute intermittent porphyria (AIP) - Gene analysis - Hydroxymethylbilane synthase (HMBS) . Molecular pathology $\cdot$ Mutations

\section{Introduction}

Acute intermittent porphyria (AIP) is generally an autosomal dominant inherited metabolic disease caused by a decreased activity of hydroxymethylbilane synthase [EC 4.3.1.8] (HMBS), the third enzyme in the human heme biosynthetic pathway (Kappas et al. 1995). AIP is clinically characterized by a propensity to acute neurovisceral crises, often precipitated by drugs, alcohol, starvation, stress, and other factors (Kappas et al. 1995). Because the avoidance of these known precipitating factors may prevent the occurrence of life-threatening attacks, the detection of carriers is very important.

The diagnosis of AIP has traditionally been based on clinical symptoms and biochemical tests, such as the determination of porphobilinogen (PBG) and deltaaminolevulinic acid (ALA) in urine, and enzyme activities (Kappas et al. 1995). Of the conventional biochemical methods, PBG and ALA concentrations are usually reliable during the acute phase of the illness, but their levels are generally lower between attacks and may even be within the reference range (Deacon 1988). The assay for erythrocyte HMBS activity is the most reliable clinical assay for diagnosing patients with AIP, whether symptomatic or latent. However, the overlapping zone of HMBS activity between that in affected patients and that in normal individuals still makes it difficult to establish a definitive diagnosis (Kappas et al. 1995; McColl et al. 1982). Therefore, the establishment of a diagnosis using molecular technology is crucial (Schreiber 1995; Schreiber et al. 1995a).

Recently, the human $H M B S$ gene has been cloned (Grandchamp et al. 1987; Chretien et al. 1988; Yoo et al. 
1993). The gene has been shown to span $11 \mathrm{~kb}$ and has two distinct promoters that generate the housekeeping and erythroid-specific transcripts by alternative splicing. The housekeeping promoter is in the $5^{\prime}$ flanking region, and its transcript contains exons 1 and 3 through 15 . The erythroidspecific promoter is in intron 1 , and its transcript contains exons 2 through 15.

Regarding the abnormalities of the $H M B S$ gene, more than 150 different mutations have been reported since 1989 (Grandchamp et al. 1989). In Japan, however, molecular analyses have been documented in only six families (Daimon et al. 1993; Daimon et al. 1994; Morita et al. 1995; Tomie et al. 1998; Maeda et al. 1999) to date.

Here, we present two additional mutations found in two unrelated Japanese AIP patients, together with reliable restriction enzyme cleavage assays to screen the family members.

\section{Subjects and methods}

Patients and control subjects. Two unrelated Japanese AIP patients, a 27-year-old woman in Niigata Prefecture and a 64-year-old man in Kagawa Prefecture, and their family members, were investigated. In each patient, the diagnosis of AIP was established by family history and clinical symptoms with biochemical findings. As normal controls for gene analysis, four unrelated healthy Japanese in our laboratory (one woman and three men; mean age, 29.8 years) were chosen. All of the subjects gave their informed consent to the study.

DNA extraction and amplification. Genomic DNA was obtained from peripheral blood leukocytes with proteinase $\mathrm{K}$ digestion and phenol/chloroform extraction. Using the extracted genomic DNA as a template, we amplified all 15 exons and flanking regions of the $H M B S$ gene by polymerase chain reaction (PCR) with 14 sets of primers, which were designed with reference to previous reports (Schreiber et al. 1994; Puy et al. 1997). Exons 5 and 6 were combined in a single amplicon. The PCR mixture contained 200ng of genomic DNA as a template, 20 pmol of each primer, dNTPs at $0.2 \mathrm{mM}$ concentration, $0.1 \mathrm{U}$ of AmpliTaq Gold (PE Biosystems, Tokyo, Japan), and supplemented buffer in a total volume of $20 \mu \mathrm{l}$. PCR was carried out under the following conditions: $5 \mathrm{~min}$ at $95^{\circ} \mathrm{C}$ and then amplification for 35 cycles. Each cycle consisted of $1 \mathrm{~min}$ at $95^{\circ} \mathrm{C}, 1 \mathrm{~min}$ at $60^{\circ} \mathrm{C}$, and $1 \mathrm{~min}$ at $72^{\circ} \mathrm{C}$ in a thermal cycler. The products were separated on $2 \%$ agarose gel to confirm the size.

Screening for the mutation. Single-strand conformation polymorphism (SSCP) analysis was used to screen all 14 amplified genomic DNA fragments of the $H M B S$ gene for the mutations. One microliter of each PCR product was added to $5 \mu \mathrm{l}$ of $95 \%$ formamide, $10 \mathrm{mmol} / 1$ of ethylenediaminetetraacetic acid (EDTA), and $0.05 \%$ bromophenol blue, and the samples were heated at $95^{\circ} \mathrm{C}$ for $5 \mathrm{~min}$, then placed on ice. The samples were immediately loaded on a
$12 \%$ polyacrylamide gel and run at $150 \mathrm{~V}$ for $6 \mathrm{~h}$ at room temperature. The DNA bands were visualized by simple silver staining (Yuasa et al. 1997).

Sequencing of DNA. PCR products of genomic DNA fragments containing the abnormal band(s) were directly sequenced. A direct sequence reaction was performed using an ABI PRISM BigDye Terminator Cycle Sequencing Kit (PE Biosystems, Tokyo, Japan). The sequencing samples were analyzed using an ABI PRISM 310 Genetic Analyzer (PE Biosystems) according to the manufacturer's instructions. Sequence data were analyzed using the software package ALF (Pharmacia, Tokyo, Japan) and GENETYXMAC software (Software Development, Tokyo, Japan).

Restriction enzyme digestive assay. The two mutations found were confirmed by digestion of the appropriate exon with a restriction enzyme that differentiated between the normal and mutant alleles. Exons 12 and 15 were amplified as described above. Each PCR product containing the specific mutation site was digested with each specific restriction endonuclease, HinfI or BsrI (New England Biolabs, Beverly, MA, USA), as recommended by the supplier. The digests were resolved on $12 \%$ polyacrylamide gel, and the bands were visualized by ethidium bromide staining under UV light. Genomic DNAs from the patients and other family members were used.

\section{Results}

SSCP analysis was performed on all 15 exons of the $H M B S$ gene, which ranged from 140 to 306 base-pairs in length. One exon at a time was analyzed, and PCR products from the two patients were run next to control samples to facilitate comparison of the banding patterns. The patients' samples gave banding patterns distinct from those of control samples in exons 12 and 15, respectively (Fig. 1). SSCP analysis of all other exons and flanking regions in the two probands did not reveal any mobility shifts resulting from mutations. Subsequently, each of these abnormal fragments a

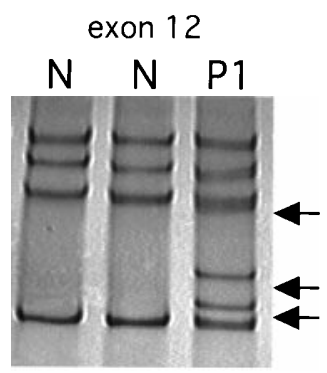

b

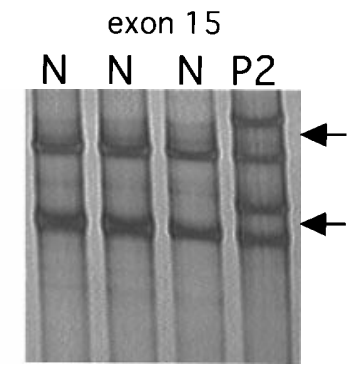

Fig. 1a,b. Single-strand conformation polymorphism (SSCP) analysis of samples from the patients and normal controls. The sample containing exon 12 from the first patient $(P 1)$ (a) and the sample containing exon 15 from the second patient $(P 2)$ (b) showed a different banding pattern (arrows) from those of normal controls $(N)$ 
from the $H M B S$ gene was directly sequenced. The numbering of the mutations is based on the translation start site of the cDNA.

In the first patient, sequencing of exon 12 revealed a twobase deletion of CT at nucleotide 730-731 (730delCT) (Fig. $2 \mathrm{a}$ ), which is responsible for a frameshift with a stop codon occurring six codons downstream. The mutation eliminates a HinfI restriction site, and a rapid screening method was established by the HinfI digestion test, using an amplified DNA fragment. The normal allele was cleaved into two fragments, while the mutated allele was not. In the family study using this digestion assay, the mutation was detected not only in the proband but also in asymptomatic individuals. Other unaffected members showed normal cleavage. These results are shown in Fig. 3a.

In the second patient, direct sequencing demonstrated a deletion mutation in exon 15 , which was also a two-base deletion of CA at position 982-983 (982delCA) (Fig. 2b). The deletion at this position shifts the reading frame, resulting in a premature stop codon occurring 29 codons downstream at amino acid position 357 , which would result in a truncated protein. The 982delCA mutation was confirmed by restriction digestion of the amplified DNA fragment by $B s r$ I. Pedigree analysis with digestion assay revealed that the daughter of the proband is not a gene carrier (Fig. 3b).

\section{Discussion}

Since 1989 (Grandchamp et al. 1989), many different mutations associated with AIP have been detected in the HMBS gene, including deletions, insertions, and missense, nonsense, and splicing mutations. The mutations are scattered throughout the gene from exon 1 to exon 15, but nearly onehalf of them are found in exons 10 and 12. It is likely that these parts of the $H M B S$ gene are critical for enzymatic function. Only exon 2 has no reported mutations, because

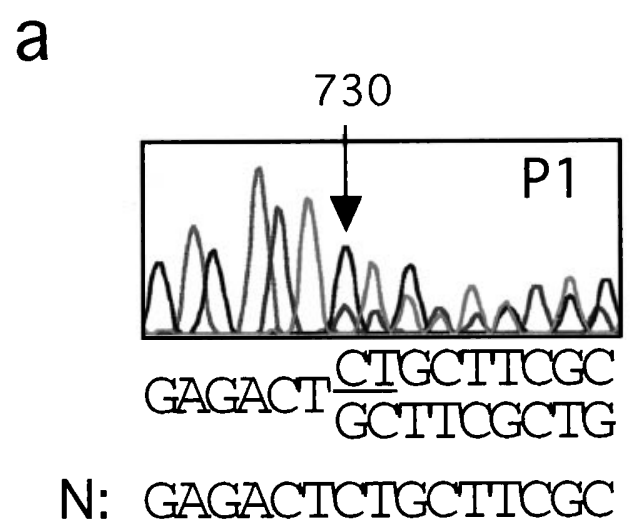

Fig. 2a,b. Direct sequencing of an amplified genomic DNA fragment from the patients. Compared with normal sequences $(N)$, a two-base deletion of CT in exon 12 of the gene at nucleotide position 730 in the first patient $(P 1)(\mathbf{a})$, and a two-base deletion of CA in exon 15 at nucleotide position 982 in the second patient $(P 2)$ (b) are observed. The underlined nucleotides and the arrows indicate deleted nucleotides the transcript of the housekeeping promoter does not contain exon 2, and exon 2 of the erythroid-specific transcript encodes no amino acids (Grandchamp et al. 1987; Chretien et al. 1988; Yoo et al. 1993).

In this study, we identified two mutations in the $H M B S$ gene. The first described deletion mutation, 730delCT, causes a frameshift resulting in a premature stop codon at codon position 248 in exon 12, which would result in a truncated protein, leading to the loss of approximately one-third of the protein. The second deletion mutation, 982delCA, a novel mutation, causes not only a frameshift resulting in a truncated protein but also a loss of glycine 335 , which is located seven amino acids downstream in the normal amino acid sequence. On the basis of the crystal model of the HMBS polypeptide purified from Escherichia coli (Louie et al. 1992; Brownlie et al. 1994), the polypeptide chain of the human enzyme is folded into three domains; exon 15 encodes amino acids in domain 3, and the amino acid Gly 335 is presumed to be crucial for the structural stability of the $\alpha$-helix in the domain. Therefore, the change in this part is most likely to impair enzyme activity. In fact, a Gly335Asp mutation has been observed in a French AIP family (Puy et al. 1997). Consequently, these mutations detected in our patients are predicted to affect the normal structure and/or function of the enzyme and are expected to be the primary cause of the disease.

These two mutations are the first found among Japanese AIP patients, but the CT deletion mutation in the first patient was the same as that previously reported in the United Kingdom (Mgone et al. 1993). In Japan, five kinds of mutations in the $H M B S$ gene have been described in six unrelated Japanese families so far (Daimon et al. 1993; Daimon et al. 1994; Morita et al. 1995; Tomie et al. 1998; Maeda et al. 1999) (Fig. 4), with four of the families having the same mutations as those reported in Europe. The mutation reported by Tomie et al. (1998) is similar to that previously reported in South Africa (Whatley et al. 1995), Sweden (Lee 1991), Canada (Schreiber et al. 1995b), Finland

b

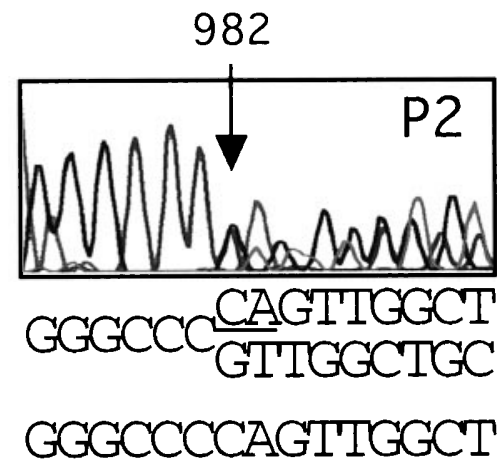

for each patient. In parts $\mathbf{a}$ and $\mathbf{b}$, the two sequences under the electrophorogram of the patient represent the superimposed sequences caused by the deletion mutation. The sequences are in the sense orientation, and the nucleotide numbers are from the translation start site of the hydroxymethylbilane synthase $(H M B S)$ cDNA 
a

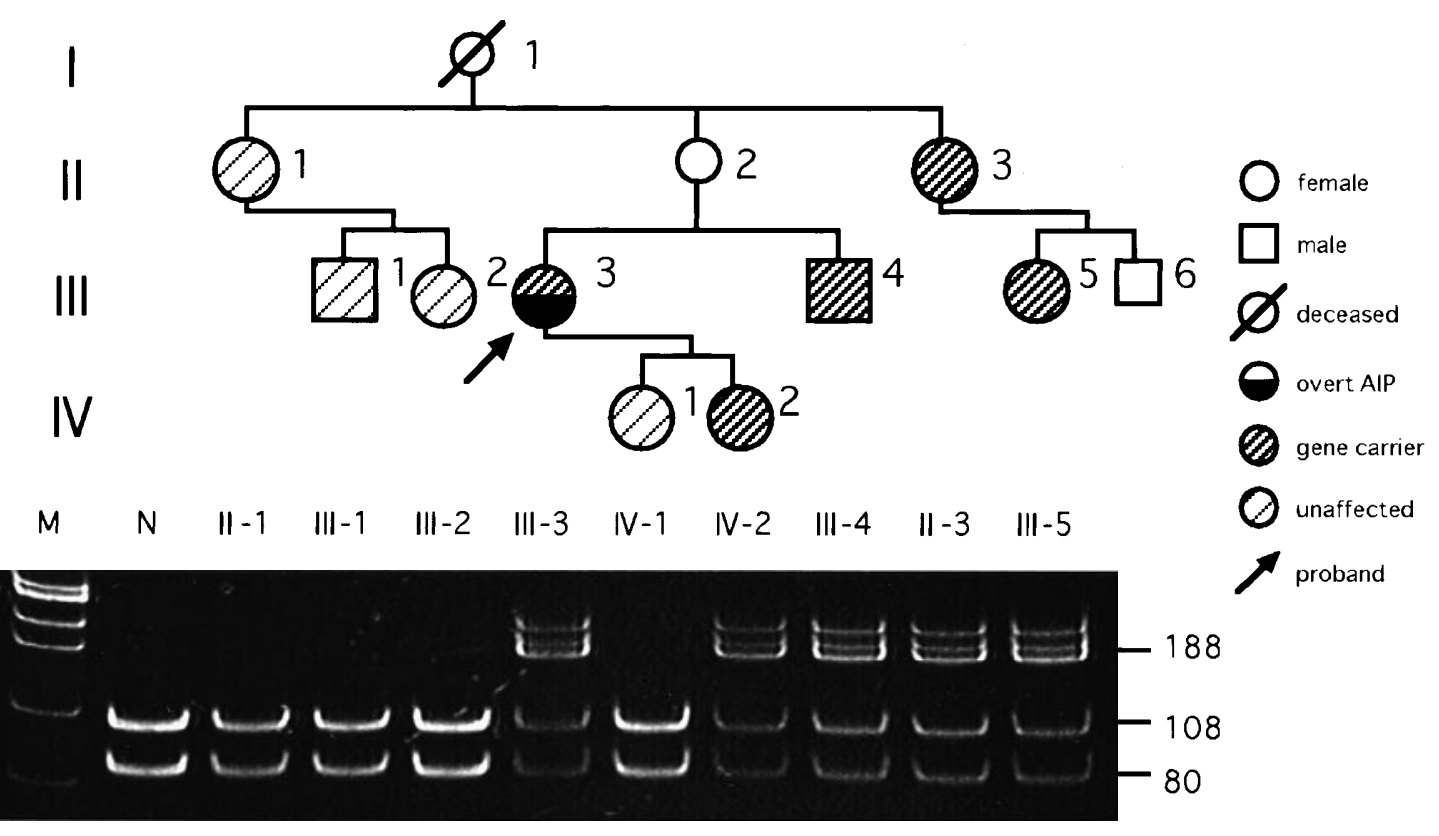

b

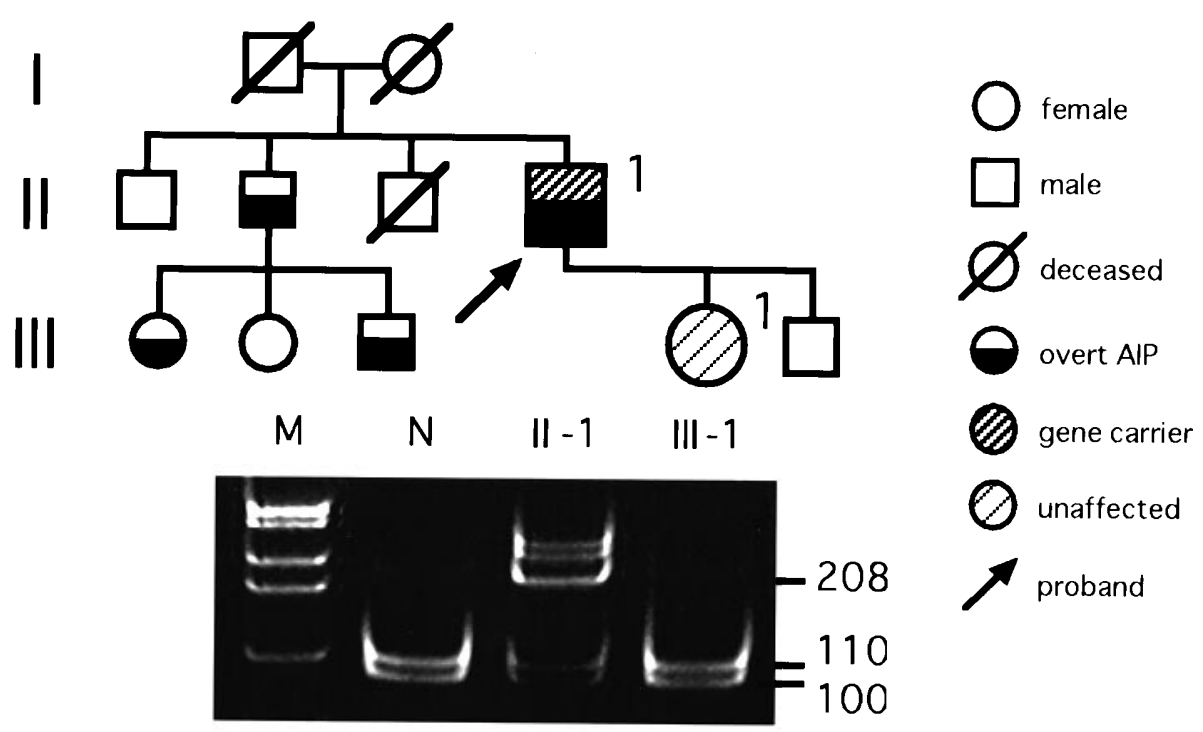

Fig. 3. a Pedigree analysis and cleavage assay with HinfI restriction endonuclease in the first patient. Symbol keys are shown to the right of the family tree. A 188-bp fragment is amplified by polymerase chain reaction (PCR) and the mutated allele is uncleaved by HinfI: $188 \mathrm{bp}$ as the mutated allele, and $108 \mathrm{bp}$ and $80 \mathrm{bp}$ as the normal allele (III-3, IV$2, I I I-4, I I-3$, and $I I I-5)$. The alleles from the normal subject $(N)$ and unaffected family members $(I I-1, I I I-1, I I I-2$, and $I V-1)$ are normally cleaved into two fragments. The fragments can be seen in the gel, and two bands, of around $188 \mathrm{bp}$, observed in gene carriers are due to heteroduplex bands. The numbers to the right of the Fig. are sizes in bp. $M$, DNA size-marker; $A I P$, acute intermittent porphyria. b Pedigree tree and cleavage analysis with $B s r \mathrm{I}$ restriction endonuclease in the second patient. Symbols as in a. The 982delCA mutation abolishes one of the BsrI restriction sites: $208 \mathrm{bp}, 34 \mathrm{bp}$, and $33 \mathrm{bp}$ as the mutated allele, with $110 \mathrm{bp}, 100 \mathrm{bp}, 34 \mathrm{bp}$ and $33 \mathrm{bp}$ as the normal allele (II-1). The bands of $34 \mathrm{bp}$ and $33 \mathrm{bp}$ are not observed in this photograph. The heteroduplex bands can be seen around the band of $208 \mathrm{bp}$. The amplified DNA fragment including exon 15 from the patient's daughter (III-1) shows similar banding patterns to that from normal control $(N)$, which were cleaved into four fragments. The numbers to the right of the Fig. are sizes in bp. $M$, DNA size-marker 


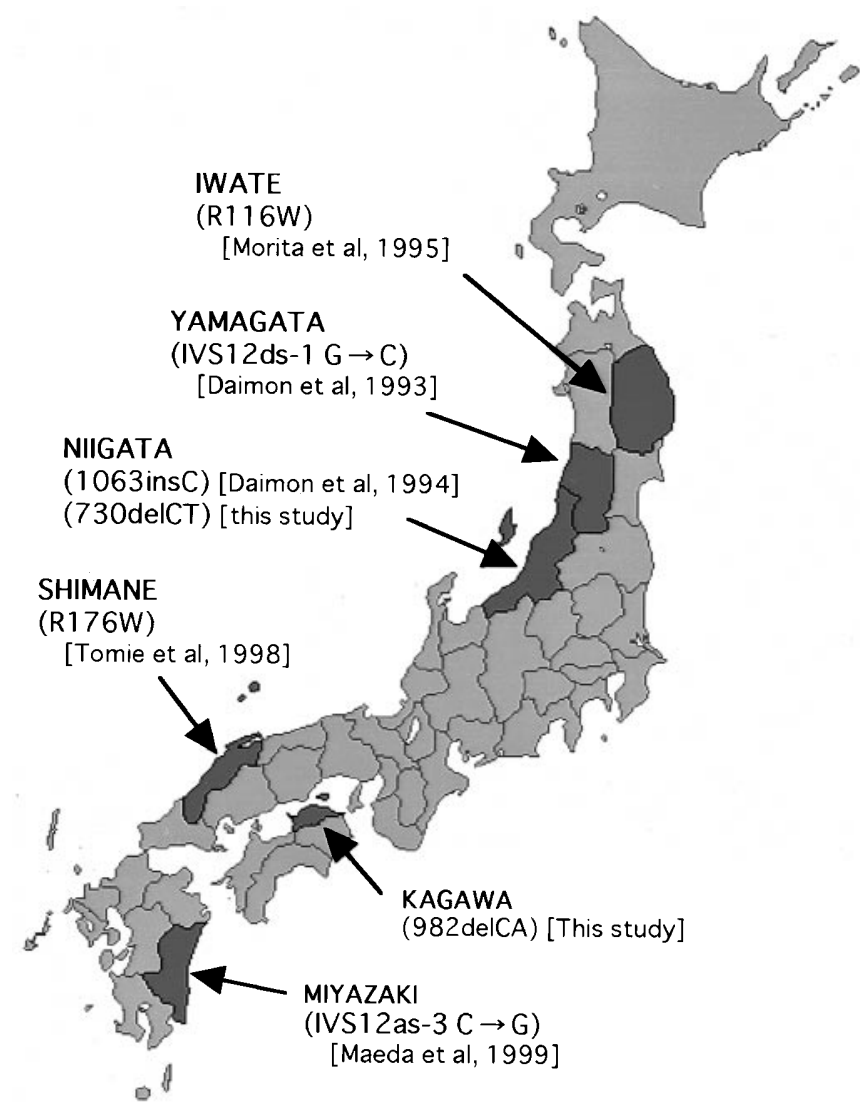

Fig. 4. Distribution map of current mutations in the $H M B S$ gene in Japanese AIP patients. The name of the prefecture is shown in boldfaced and each mutation is shown in parenthesis under the prefecture name. Authors' names are shown in brackets. $d s$, donor site; as, acceptor site

(Kauppinen et al. 1995), France (Puy et al. 1997), and elsewhere. It is a point mutation modifying codon 173 in exon 10: a C-to-T transition at position 517 led from an arginine to tryptophan substitution (R173W). Recently, this mutation has been documented as the first mutation in AIP associated with a founder effect in North America with the identified founding couple (Greene-Davis et al. 1997). Such a founder effect has been well documented in variegate porphyria, the other form of acute porphyria (Dean 1971; Meissner et al. 1996; Warnich et al. 1996; Groenewald et al. 1998), and has also been observed in other AIP patients (De Siervi et al. 1999). The other mutation in Japan, reported by Morita et al. (1995), is a single base substitution C-to-T in exon 8 of the gene, which was the same as a common mutation in the Netherlands (Gu et al. 1994). This patient was diagnosed in Northeast Japan, and this area has been called "Holland Village". Moreover, a splicing mutation recently reported by Maeda et al. (1999) is similar to that from the Netherlands (Llewellyn et al. 1996): a C-to-G transversion at position -3 of the acceptor site of intron 11 leading to exon 12 skipping. Such a similarity of gene abnormality may suggest that these European and Japanese AIP families could have a common ancestor. It is not clear, however, whether our first patient and the patient(s) reported from the United Kingdom (Mgone et al. 1993) have a common ancestor or not. In our patient, it may be more likely that the mutation happened de novo in a maternal ancestor of her family, because there is no evidence to support the idea that the family is related to any individuals from other countries, including the United Kingdom. It is necessary to examine many other AIP patients for the mutation in order to answer the question of whether these mutations can have common ancestors as a result of a founder effect on a worldwide level.

In AIP, the diagnosis of asymptomatic heterozygotes is important, because the avoidance of known precipitating factors such as drugs, alcohol, fasting, cyclical hormonal changes, or infectious diseases, will prevent the occurrence of life-threatening neurovisceral attacks (Kappas et al. 1995). Enzymatic assays and DNA-based testing are not usually needed for the rapid diagnosis or management of symptomatic subjects for the cost-effective diagnosis of porphyric syndromes (Bonkovsky and Barnard 1998), and, in regard to the identification of asymptomatic carriers, the best clinical laboratory test is the measurement of erythrocytic HMBS activity. However, Schreiber et al. (1995b) reported that 4 of 36 family members were incorrectly classified by the enzyme assay when their group compared the performance of erythrocytic HMBS activity measurement with direct mutation analysis in an AIP family. In our family study, using a cleavage assay, asymptomatic carriers were definitively identified and the remainder of the family, who had undergone gene analyses, were decidedly excluded as gene carriers. Once a mutation has been characterized, the testing of family members is straightforward, and gene carriers can be identified or excluded with greater accuracy than is possible with conventional biochemical tests (Schreiber 1995). Thus, it is of great benefit to AIP families when the actual mutation in the family is detected, and additional molecular investigations of the AIP family members should be employed for a more accurate diagnosis, especially for asymptomatic heterozygotes so that they may avoid porphyric attacks in the future.

AIP is the most important form of hepatic porphyria, because of its severe clinical symptoms, and continued efforts to find the specific mutations in other AIP families will provide not only improved diagnosis, particularly for asymptomatic heterozygotes, as the basis for proper genetic counseling but also an increased understanding of the molecular genetic heterogeneity underlying this dominantly inherited enzymopathy.

Acknowledgments The authors are indebted to Professor Mitsuo Oshimura, Department of Molecular and Cell Genetics, Faculty of Medicine, Tottori University, for sequencing.

\section{References}

Bonkovsky HL, Barnard GF (1998) Diagnosis of porphyric syndromes: a practical approach in the era of molecular biology. Semin Liver Dis 18:57-65

Brownlie PD, Lambert R, Louie GV, Jordan PM, Blundell TL, Warren MJ, Cooper JB, Wood SP (1994) The three-dimensional 
structures of mutants of porphobilinogen deaminase: toward an understanding of the structural basis of acute intermittent porphyria. Protein Sci 3:1644-1650

Chretien S, Dubart A, Beaupain D, Paith PH, Grandchamp B, Rosa J, Goossens M, Romeo PH (1988) Alternative transcription and splicing of the human porphobilinogen deaminase gene results either in tissue-specific or in housekeeping expression. Proc Natl Acad Sci USA 85:6-10

Daimon M, Yamatani K, Igarashi M, Fukase N, Ogawa A, Tominaga M, Sasaki H (1993) Acute intermittent porphyria caused by a $\mathrm{G}$ to $\mathrm{C}$ mutation in exon 12 of the porphobilinogen deaminase gene that results in exon skipping. Hum Genet 92:549-553

Daimon M, Yamatani K, Igarashi M, Fukase N, Morita Y, Ogawa A, Tominaga M, Sasaki H (1994) Acute intermittent porphyria caused by a single base insertion of $\mathrm{C}$ in exon 15 of the porphobilinogen deaminase gene that results in a frame shift and premature stopping of translation. Hum Genet 93:533-537

Deacon AC (1988) Performance of screening tests for porphyria. Ann Clin Biochem 25:392-397

Dean G (1971) The porphyrias: a story of inheritance and environment, 2nd edn. Pitman Medical, London, pp 1-170

De Siervi A, Rossetti MV, Parera VE, Astrin KH, Aizencang GI, Glass IA, Batlle AM, Desnick RJ (1999) Identification and characterization of hydroxymethylbilane synthase mutations causing acute intermittent porphyria: evidence for an ancestral founder of the common G111R mutation. Am J Med Genet 86:366-75

Grandchamp B, de Verneuil H, Beaumont C, Chretien S, Walter O, Nordmann Y (1987) Tissue-specific expression of porphobilinogen deaminase. Two isozymes from a single gene. Eur J Biochem 162: 105-110

Grandchamp B, Picat C, de Rooij F, Beaumont C, Wilson P, Deybach JC, Nordmann Y (1989) A point mutation G-A in exon 12 of the porphobilinogen deaminase gene results in exon skipping and is responsible for acute intermittent porphyria. Nucleic Acids Res 17:6637-6649

Greene-Davis ST, Neumann PE, Mann OE, Moss MA, Schreiber WE, Welch JP, Langley GR, Sangalang VE, Dempsey GI, Nassar BA (1997) Detection of a R173W mutation in the porphobilinogen deaminase gene in the Nova Scotian "foreign protestant" population with acute intermittent porphyria: a founder effect. Clin Biochem 30:607-612

Groenewald JZ, Liebenberg J, Groenewald IM, Warnich L (1998) Linkage disequilibrium analysis in a recently founded population: evaluation of the variegate porphyria founder in South African Afrikaners. Am J Hum Genet 62:1254-1258

Gu XF, de Rooij F, Voortman G, Te Velde K, Deybach JC, Nordmann Y, Grandchamp B (1994) Detection of 11 mutations causing acute intermittent porphyria using denaturing gradient gel electrophoresis. Hum Genet 93:47-52

Kappas A, Sassa S, Galbraith RA, Nordmann Y (1995) The porphyrias. In: Scriver CR, Beaudet AL, Sly WS, Valle D (eds) The metabolic and molecular basis of inherited disease, 7th edn. McGraw-Hill, New York, pp 2103-2159

Kauppinen R, Mustajoki S, Pihlaja H, Peltonen L, Mustajoki P (1995) Acute intermittent porphyria in Finland: 19 mutations in the porphobilinogen deaminase gene. Hum Mol Genet 4:215-222

Lee JS (1991) Molecular genetic investigation of the human porphobilinogen deaminase gene in acute intermittent porphyria. Stockholm, Repro Print AB, pp 1-50

Llewellyn DH, Scobie GA, Urquhart AJ, Whatley SD, Roberts AG Harrison PR, Elder GH (1996) Acute intermittent porphyria caused by defective splicing of porphobilinogen deaminase RNA: a synonymous codon mutation at -22 bp from the $5^{\prime}$ splice site causes skipping of exon 3. J Med Genet 33:437-438
Louie GV, Brownlie PD, Lambert R, Cooper JB, Blundell TL, Wood SP, Warren MJ, Woodcock SC, Jordan PM (1992) Structure of porphobilinogen deaminase reveals a flexible multidomain polymerase with a single catalytic site. Nature 359:33-39

Maeda N, Horie Y, Sasaki Y, Ueta E, Adachi K, Nanba E, Kawasaki H, Kudo Y, Kondo M (1999) A splicing mutation in the hydroxymethylbilane synthase gene in a Japanese family with acute intermittent porphyria. Clin Biochem 32:411-417

McColl KEL, Moor MR, Thompson GG, Goldberg A (1982) Screening for latent acute intermittent porphyria: the value of measuring both leukocyte delta-aminolevulinic acid synthetase and erythrocyte uroporphyrinogen-I-synthetase activities. J Med Genet 19:271-276

Meissner PN, Dailey TA, Hift RJ, Ziman M, Corrigall AV, Roberts AG, Meissner DM, Kirsch RE, Dailey HA (1996) A R59W mutation in protoporphyrinogen oxidase results in decreased enzyme activity and is prevalent in South Africans with variegate porphyria. Nature Genet 13:95-97

Mgone CS, Lanyon WG, Moor MR, Louie GV, Connor JM (1993) Detection of a high mutation frequency in exon 12 of the porphobilinogen deaminase gene in patients with acute intermittent porphyria. Hum Genet 92:619-622

Morita Y, Daimon M, Kashiwaba M, Yamatani K, Igarashi M, Fukase N, Ohnuma H, Ikezawa Y, Sugiyama K, Manaka H, Tominaga M, Sasaki H (1995) A point mutation, C to T, in exon 8 of the porphobilinogen deaminase gene in a Japanese family with acute intermittent porphyria. Jpn J Hum Genet 40:207-213

Puy H, Deybach JC, Lamoril J, Robreau AM, Da Silva V, Gouya L, Grandchamp B, Nordmann Y (1997) Molecular epidemiology and diagnosis of PBG deaminase gene defects in acute intermittent porphyria. Am J Hum Genet 60:1373-1383

Schreiber WE, Fong F, Jamani A (1994) Frameshift mutations in exon 1 and 10 of the porphobilinogen deaminase gene produce a crossreacting immunological material (CRIM)-negative form of acute intermittent porphyria. Hum Genet 93:552-556

Schreiber WE (1995) Acute intermittent porphyria: laboratory diagnosis by molecular methods. Clin Lab Med 15:943-956

Schreiber WE, Fong F, Nassar BA, Jamani A (1995a) Heteroduplex analysis detects frameshift and point mutations in patients with acute intermittent porphyria. Hum Genet 96:161-166

Schreiber WE, Jamani A, Armstrong JG (1995b) Acute intermittent porphyria in a native North American family. Biochemical and molecular analysis. Clin Chem 103:730-734

Tomie Y, Horie Y, Tajima F, Kitaoka S, Nanba E, Yuasa I, Kawasaki H (1998) The mutation, in exon 10 (R173W) of the hydroxymethylbilane synthase gene in two unrelated Japanese families with acute intermittent porphyria. Res Commun Mol Pathol Pharmacol 99:5-15

Warnich L, Kotze MJ, Groenewald IM, Groenewald JZ, van Brakel MG, van Heerden CJ, de Villiers JN, van de Ven WJ, Schoenmakers EF (1996) Identification of three mutations and associated haplotypes in the protoporphyrinogen oxidase gene in South African families with variegate porphyria. Hum Mol Genet 3:981984

Whatley SD, Roberts AG, Elder GH (1995) De novo mutation and sporadic presentation of acute intermittent porphyria. Lancet 346: 1007-1008

Yoo HW, Warner CA, Chen CH, Desnick RJ (1993) Hydroxymethylbilane synthase: complete genomic sequence and amplifiable polymorphisms in the human gene. Genomics 5:21-29

Yuasa I, Umetsu K, Vogt U, Nakamura H, Nanba E, Tamaki N, Irizawa Y (1997) Human orosomucoid polymorphism: molecular basis of the three common ORM1 alleles, ORM1*F1, ORM1*F2, and ORM1*S. Hum Genet 99:393-398 